\title{
Hvor ble det av influensa A(H1N1)-serologien?
}

\author{
I september 2009 ble vi gjort oppmerksom på at ingen laboratorier i Norge utførte influensaserologi, \\ kun antigenpåvisning. Dette finner vi betenkelig, da det er en vesensforskjell mellom antigenpåvisning \\ (f.eks. polymerasekjedereaksjon) og antistoffpåvisning (serologi). Vi vil anbefale å kombinere agens- \\ påvisning og serologisk undersøkelse.
}

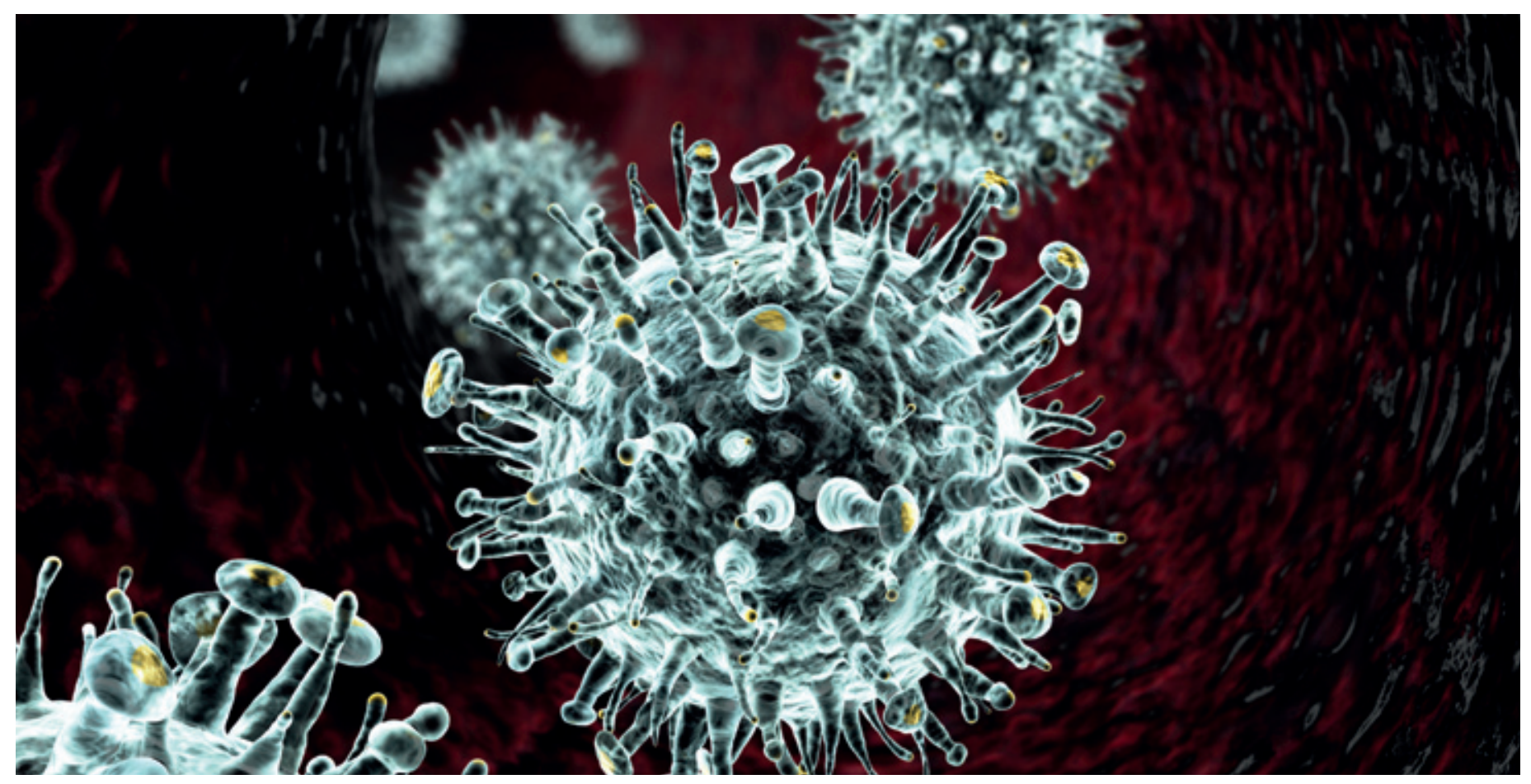

Foto: istockphoto.com

Antigenpåvisning viser at antigen (bakterier, virus) er til stede, mens serologisk undersøkelse kan påvise infeksjon. Infeksjon er per definisjon at smitte trenger inn i kroppen og at kroppen reagerer på inntrengeren ved å produsere antistoffer. Etter denne definisjonen vil også vaksine gi infeksjon. Det er derfor en god idé å kombinere agenspåvisning med serologi.

\section{Serologi}

For å se i hvilken grad influensa A (H1N1)vaksinering kunne avspeiles serologisk, satt vi opp en komplementbindingsreaksjon rettet mot virale nukleo- og matriksproteiner som finnes i alle influensa A-virus. Antistoff mot nukleo- og matriksproteiner er velegnet til å påvise gjennomgått influensa A-sykdom, men sier ikke noe om hvilken H- eller N- type vi har med å gjøre. For H- og N-typing er en nøytralisasjonstest velegnet, men den krever levende virus, noe vårt laboratorium ikke hadde adgang til.

Komplementbindingsreaksjon utføres ikke maskinelt, men er komplisert og arbeidskrevende. Den kan likevel være meget pålitelig i øvede hender. Firefolds titerstigning eller mer kreves for å konklu- dere sikkert med aktuell infeksjon. Antinukleo- og antimatriksproteinantistoffer mot influensa A synker relativt hurtig fra toppverdi, dvs. de holder seg mindre enn et år. De fleste som utfører komplementbindingsreaksjonsserologi regner et titer $\geq 80$ for signifikant tegn på infeksjon (sykdom eller vaksine) (G. Hoddevik, personlig meddelelse).

\section{Mål på vaksinerespons}

For å stille diagnosen svineinfluensa har norske laboratorier med hell benyttet polymerasekjedereaksjonstest (PCR). Denne metoden er utmerket til å påvise spor av virus i nesesekret, men bør ikke få stå alene. Man kan ved PCR påvise smitte eller kontaminasjon, men ikke sikker aktuell sykdom og aldri tidligere gjennomgått sykdom. Ved serologi vil man kunne fortelle om pågående eller tidligere gjennomgått sykdom eller vaksinasjon, men ikke skille mellom disse.

Bruk av oljebasert adjuvans er velkjent praksis i eksperimentell infeksjonsserologi for å forsterke eller forlenge et immunsvar. A(H1N1)-vaksinen inneholder adjuvans (squalener), i motsetning til sesonginfluensavaksinen. Dette fordi A(H1N1)-vaksinen inneholder mindre antigen enn sesongvak- sinen. Hvorvidt en vaksinedose ville være tilstrekkelig, kunne vært målt med serologi og meddelt allerede tidlig i vaksinasjonskampanjen.

Pandemivaksine representerer et kostbart giganttiltak. I det halve året som gikk fra pandemien var et faktum og til vaksinasjonsstart, kunne man ha planlagt en tidlig serologisk oppfølging etter vaksinasjon med utgangspunkt $i$ en serumprøve av pasientene før vaksinasjon.

År 2009 er ikke siste gang vi har en influensapandemi. Ved å la serologi inngå i undersøkelsen ved neste pandemi vil vi lære mer om hvorledes infeksjonen sprer seg $\mathrm{i}$ befolkningen.

\section{Olaf Scheel}

olafscheel@hotmail.com

Sandra Helland

Bente Karlsen

Forsvarets mikrobiologiske laboratorium Postboks 4302 Nydalen

0402 Oslo

\section{Oppgitte interessekonflikter: Ingen}

